\title{
マコンブ中のヒ素の化学形態についで*
}

(昭和 57 年 7 月 19 日受理)

\author{
吉田政晴 ${ }^{* 2}$ 田中凉一 ${ }^{* 2}$ 樫本 隆*2
}

\section{Chemical Form of Arsenic in Makonbu, Laminaria japonica Aresh.}

(Studies on Arsenic Compounds in Makonbu, Laminaria japonica Aresh. I)

\author{
Masaharu Yoshida, Ryoichi TANAKA and Takashi Kashimoto \\ (Osaka Prefectural Institute of Public Health: 3-69, Nakamichi 1-chome, \\ Higashinari-ku, Osaka, Japan)
}

The chemical form of arsenic in Laminaria japonica Aresh. (Japanese name: "makonbu", Laminariaceae) was investigated and the following results were obtained.

1) The arsenic in "makonbu" is easily extracted with water-methanol (4:1) mixture (the recovery was more than $90 \%$ ).

2) Ultrafiltration indicated that the water-methanol soluble arsenic compounds have low molecular weight (MW 500-1,000).

3) In activated charcoal column chromatography, the arsenic compounds in "makonbu" were eluted with water-ethanol $(4: 1)$ mixture, but not with water (column recovery 99. 2\%). In QAE-Sephadex A-25 (Cl type) column chromatography, the arsenic compounds in "makonbu" were eluted with acetic acid-methanol (1:25) mixture (column recovery $80.1 \%$ ). After both procedures, the content of arsenic in the eluate reached $2.78 \%$.

4) The arsenic compounds gave negative reactions with ninhydrin, dithizon and phenol-sulfuric acid reagent.

(Received July 19, 1982)

Key words: 化学形態 chemical form; マコンブ sea tangle (Laminaria japonica Aresh.); ヒ素 arsenic; ゲルろ過 gel filtration; 限外ろ過 ultrafiltration; カラムクロマトグラフィー column chromatography; 薄層クロマトグラフィー thin layer chromatography

\section{まえがき}

七素は広範な生物種中に見い出され, 特に海洋生物で は陸上生物にくらべてかなり高い七素含有量を示してい $ろ^{1) \sim 4)}$. そして Lunde ${ }^{5)}$ らは海洋生物中の七素は, その 大部分が有機七素化合物であると報告している. 一般に 重金属の毒性及び生体内挙動を追究する際, その化学形 態を明確にすることがその毒性を評価するらえで重要で ある. 従来海洋生物中の七素の化学形態については Edmonds ${ }^{6)}$ ら, 品川ら*3がイセエビやミズダコからアルセ

*1 マコンブ中のヒ素化合物に関する研究（第 1 報）

*2 大阪府立公衆衛生研究所: 大阪市東成区中道 1-369

*3 品川 明ら：日本水産学会春季講演 要旨集 p. 261 (1982)
ノベタインの存在を明らかにしている。またヒジキ中の 七素については, 分子量 $200 \sim 1,500$ の有機七素化合 物7).8) であり, 塩酸（pH 2) 酸性で容易に無機化すると の報告9) がある. コンブのと素についてはゲルろ過パタ ーンがヒジキと異なるほが， $2 N$ 塩酸で無機化しな (99，などの報告があるものの詳細は不明である. そこ で著者らはコンブ中のヒ素の化学形態を明らかにする目 的で, 溶出剤, 及び活性炭, QAE-Sephadex, 薄層など のクロマトグラフィーを用い強酸, 強アルカリを使用せ ずに精製することに留意して実験を行い若干の知見を得 たので報告する.

\section{実験方法}

1. 試料

大阪市内で購入した北海道産マコンブ (55 $\mu \mathrm{g} \mathrm{As} / \mathrm{g})$ 
を用いた。 また比較のためにメタンアルソン酸ナトリウ ム, ジメチルアルシン酸ナトリウム: Sigma 社製, フェ ニルアルソン酸: 片山化学工業 (侏) 製, 覀ヒ酸カリウム: 和光純薬工業 (株) 製を対照試料とした。

\section{2. 試薬及び試料}

(a) メタノール，エタノール：和光純薬工策 (株) 製 残留農薬用

(b) ジェチルジチオカルバミン酸銀：(株) 同仁化学 研究所製

(c) Sephadex G-10, G-15, QAE-Sephadex A-25 (C1-型) : Pharmacia 社製

(d) 限外ろ過用ウルトラフィルター UK-10 (分画 分子量 10,000 ), $\mathrm{UH}-1$ (分画分子量 1,000 ): 東洋濾紙 (株)製, UM-05 (分画分子量 500)：Amicon 社製

(e) 塩酸, 砂状亜鉛：和光純薬工業 (侏) 製七素分析 用

（f） 活性炭：和光純薬工業(株) 製クロマトグラフ用

（g）薄層クロマトグラフィー（以下 TLC）用展開 溶媒： $n$-ブタノールーアセトン $-28 \%$ アンモニアー水 $(10: 10: 2: 5)$

その他試薬は特級品を使用した。

\section{3. 装星・器具}

(a) TLC 用展開槽: $8 \times 24 \times 25 \mathrm{~cm}$ カマグ社製

(b) TLC プレート: Schleicher \& Schüll 社製 PLC-セルロースプレート (厚さ $0.5 \mathrm{~mm}$ )

(c) ウルトラターラックス: Janke \& Kunkel 社製 TP 18-10

(d) フラクションコレクター：東洋濾紙(侏) 製 SF$160 \mathrm{~K}$

（e）限外万過装置：東洋濾紙（株）製 UHP-43, UHP-62

(f) 分光光度計：日立 124 Spectrophotometer

\section{4. 七素浱度測定}

微量ヒ素の測定には原子吸光法 ${ }^{10)}$, 二波長クロマトス キャナを利用したグートツァイト法，などがあるが，著 者らは実験室で容易に測定でき, しかも感度, 精度とも にすぐれているジェチルジチオカルバミン酸銀法（以下 Ag-DDTC 法) ${ }^{11)}$ を採用した。

\section{5. 七素化合物の抽出}

マコンブは市販の状態で細切し， $1 \mathrm{~g}$ 当り $4 \mathrm{ml}$ の割 合で水一メタノール混液 $(4: 1)$ を加光, ウルトラターラ ックスで粉砕抽出した。抽出液を 1 夜放置後, 東洋濾紙 No. 4 を用いて吸引ろ過を行い試験溶液 I とした.

\section{6. 活性炭カラムクロマトグラフィー}

試験溶液 I を $4 \mathrm{ml}$ (試料 $4 \mathrm{~g}$ に相当) を活性炭カラ 么 $(1 \times 5 \mathrm{~cm})$ に吸着させ, 蒸留水 $150 \mathrm{ml}$ で洗浄の後, 七素化合物をエタノールー水 $(1: 4)$ 混液 $150 \mathrm{ml}$ で溶出 し，試験溶液 II とした。
7. QAE-Sephadex A-25 カラムクロマトグラフィー あらかじめ水で膨潤させて作成した QAE-Sephadex A-25 カラム $(1 \times 15 \mathrm{~cm})$ に試験溶液 II を $10 \mathrm{ml}$ (試料 $10 \mathrm{~g}$ に相当) 吸着させ, 蒸留水 $100 \mathrm{ml}$ で洗浄の後酢 酸ーメタノール (1:25) 混液 $300 \mathrm{ml}$ でヒ素化合物を溶出 した.

\section{8. ゲルろ過}

試験溶液 II を $5 \mathrm{ml}$ 及び刘照試料のメタンアルソン 酸ナトリウム, ジメチルアルシン酸ナトリウム, フェニ ルアルソン酸, 亜ヒ酸カリウムをそれぞれ $1 \mathrm{ml}(50 \mu \mathrm{g} /$ m1) Sephadex G-10 $(2.5 \times 95 \mathrm{~cm})$ 及び Sephadex G-15 (2.5×95 cm) に加え, ゲルろ過 $(0.1 M$ 塩化ナト リウム溶液, $10 \mathrm{ml} / \mathrm{hr})$ を行い, その溶出液 $(5 \mathrm{ml} /$ tube) について, Ag-DDTC 法によるヒ素の測定を行 らとともに，還元糖類との関連性を見るために，各フラ クションをフェノール・硫酸法 ${ }^{12)} に よ り 490 \mathrm{~nm}$ におけ る吸光度を測定した.

\section{9. セルロース TLC}

活性炭カラムと QAE-Sephadex A-25 カラムで精製 したヒ素化合物について，七ルロースプレート $(20 \times 20$ $\mathrm{cm})$ を用い, $n$-ブタノールーアセトン $-28 \%$ アンモニアー 水 $(10: 10: 2: 5)$ を展開溶媒として展開し，0.1\% ジチゾ ン・クロロホルムの噴簿及び $5 \%$ 塩化第一スズ-6 $M$ 塩 酸溶液を噴霧乾燥後 $15 \%$ ヨウ化カリウムを噴霧する方 法 ${ }^{13)}$ を用いた発色によりヒ素の検出を行った. 試料中の ヒ素化合物はこれらの発色試薬で呈色しなかったので, 展開後の七ルロースプレートを原点から $5 \mathrm{~mm}$ づつか き取り, 径 $1 \mathrm{~cm}$ のミニカラムにつめ, 蒸留水 $10 \mathrm{ml}$ で 溶出させた，溶出液中の七素は，硫酸硝酸分解の後 Ag-DDTC 法で測定した.

\section{0. 限外了過}

試験溶液 II（試料 $1 \mathrm{~g} / \mathrm{ml}$ に相当）を限外ろ過用ウル トラフィルター UK-10, UH-1, UM-05 をそれぞれ七 ットした限外ろ過装置に加え, 窒素加圧下 $\left(3 \mathrm{~kg} / \mathrm{cm}^{2}\right)$ でろ過を行った。なお内液は水 $5 \mathrm{ml}$ で 2 回洗浄した。

\section{結果と考察}

\section{1. 抽出溶媒の検討}

乾燥マコンブの中に含まれるヒ素化合物の抽出率の検 討を各種の溶媒を用いて行った.

この結果, 試料 $(55 \mu \mathrm{g} \mathrm{As} / \mathrm{g})$ 中のと素化合物は Fig. 1 に示すごとく水一メタノール系溶媒に比較的よく抽出 され，特に水一メタノール (4:1) では $90 \%$ 以上のヒ素 化合物の溶出が見られた。よって以後, この溶媒を抽出 溶媒とすることにした。

\section{2. マコンブ中のヒ秦化合物と市販ヒ素化合物のゲル}

\section{ろ過クロマトクラフィー}

市販ヒ素化合物と試料中のヒ素化合物のゲルろ過を Sephadex G-10 カラムを用いて行ったときの溶出パタ ーンを Fig. 2 に示した. 


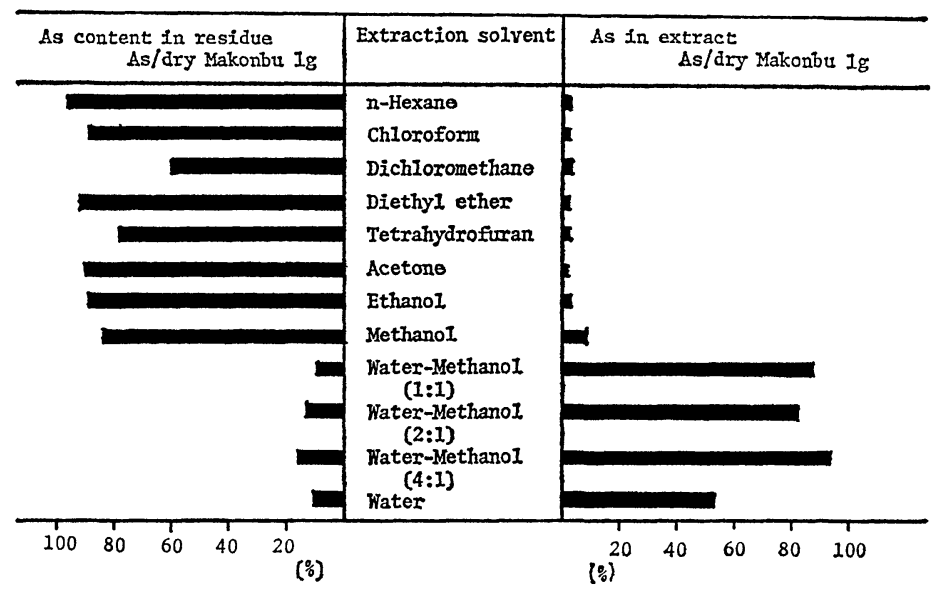

Fig. 1. As-content in makonbu extracted with various solvents

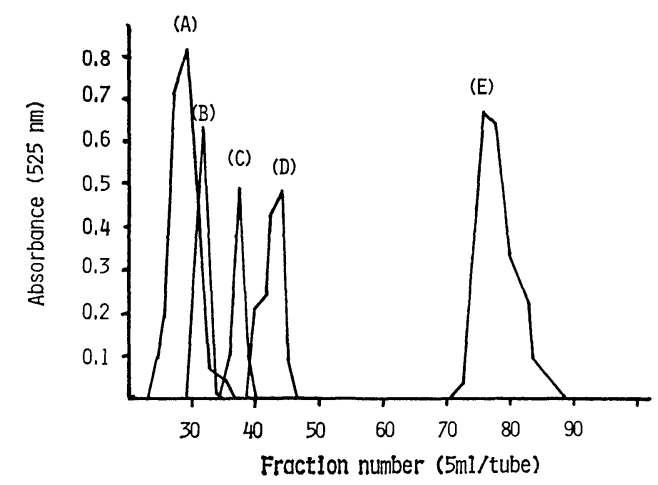

Fig. 2. Sephadex G-10 gel filtration chromatogram

Column size, $2.5 \mathrm{~cm} \times 95 \mathrm{~cm}$; solvent, $0.1 \mathrm{M}-\mathrm{KCl}$; flow rate, $10 \mathrm{ml} / \mathrm{hr}$

Peaks: (A), As in makonbu; (B), methane arsonic acid (MW, 139.9); (C), dimethyl arsinic acid (MW, 137.9); (D), phenyl arsonic acid (MW, 202.0); (E), potassium arsenite (MW, 146.0)

その結果から, 試料中の七素化合物は対照市販試料の 何れとも一致せず, メタンアルソン酸ナトリウム, ジメ チルアルシン酸ナトリウム, フェニルアルソン酸, 及び 亜ヒ酸カリウムよりも溶出が速く, このことから試料中 の七素化合物は，これらの市販試料より高分子量を有す る化合物ではないかと考えられた.

\section{3. 活性炭カラムクロマトグラフィーによる精製}

試料抽出液中の七素化合物の精製を目的として, 活性 炭カラムを用いて検討した結果，七素化合物の大部分は 活性炭に吸着し, エタノールー水 $(1: 4)$ 混液で溶出され ることが判明した. その際, カラムからのヒ素化合物の 溶出は, 注入七素量の $99.2 \%$ に相当し, このヒ素化合

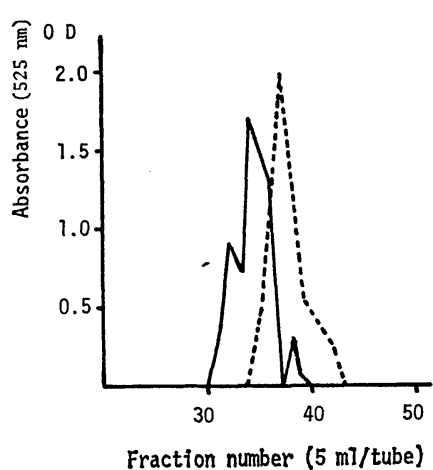

Fig. 3. Gel filtration profile of As-compound on Sephadex G-15 after the treatment with activated charcoal column chromatography

Column size, $2.5 \mathrm{~cm} \times 95 \mathrm{~cm}$; solvent,

$0.1 M-\mathrm{KCl}$; flow rate, $10 \mathrm{ml} / \mathrm{hr}$

-, $\mathrm{A}_{525}$ As in makonbu; ---, $\mathrm{A}_{480}$ reducing sugar

物がマコンブ中の水溶性七素化合物の大部分を占めてい ると思われる.またこのときのと素含有量は $0.54 \%$ で, 活性炭カラムがヒ素化合物の精製に極めて有効であるこ とを示している.

\section{Sephadex G-15 カラムによるゲルろ過}

活性炭カラムクロマトグラフィーで精製した試験溶液 II について, Sephadex G-15 カラムでのゲルろ過パタ ーンを調べた。（Fig. 3)

各フラクションについて還元糖類との関連性を見るた めに,フェノール・硫酸法による $490 \mathrm{~nm}$ における吸光 度を測定するとともに，Ag-DDTC 法によると素の测 定を行ったところ，フェノール・硫酸陽性物質が試料中 のヒ素化合物にやや遅れて溶出することが判明した. し かし溶出位置がややずれていることからマコンブ中のヒ 
素とは直接関係ないものと考えられる.この時のヒ素含 有量は $1.36 \%$ であった.

5. QAE-Sephadex A-25 カラムクロマトグラフィー による精製

活性炭カラムで精製した試験溶液 II をさらに精製す る目的で強陰イオン交換体の QAE-Sephadex A-25 (C1-型) カラムを用いて検討を行ったところ, 活性炭カ ラムで除去出来なかったフェノール・硫酸陽性物質は水 洗により溶出することが明らかになった．またこのとき のヒ素化合物の挙動を調べたところ, 水では溶出せず酢 酸ーメタノール混液で溶出することが判明した。この事 実はヒ素化合物が何らかのアニオン基をその構成成分中 に有している可能性を示唆している.酢酸濃度は検討の 結果から酢酸-メタノール (1:25) 混液が適していた。こ のときのカラムからの七素化合物の溶出は, 注入七素量 の $80.18 \%$ に相当し，このときのヒ素含有量は $2.78 \%$ であった。

\section{6. 七絭化合物の TLC}

（3）（5）によって精製した試料中のヒ素化合物と対照 市販ヒ素化合物のクロマトグラムを Fig. 4 に示す.

対照市販七素化合物（七素含有量 $0.5 \%$ ）はジチゾン, 塩化第一スズーヨウ化カリウムなどの発色試薬ですべて 呈色し，それぞれの $\mathrm{R} f$ 值はメタンアルソン酸ナトリウ

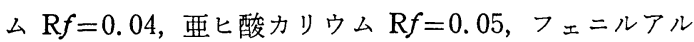
ソン酸 $\mathrm{R} f=0.12$, ジメチルアルシン酸ナトリウム $\mathrm{R} f=$ 0.13 であった．しかし試料中の七素化合物は，七素含有 量が $2.78 \%$ と対照試料にくらべてかなり高濃度にもか かわらず，いずれの発色試薬とも反応しなかった．この ことは, マコンブ中のヒ素化合物は対照市販ヒ素化合物 とは異なった化学形態を有していることを示すものであ る.そこで試料中のと素化合物を確認する目的で TLC プレートの原点から $5 \mathrm{~mm}$ ずつ薄層をかきとりヒ素を 測定する方法を用いて $\mathrm{Rf}$ 值を求めたところ 0.13 0.32 でかなりテーリングしたスポットが観察された. ヒ素濃度の測定では， 2 か所にピークが存在するので， あるいは 2 種類のヒ素化合物の存在が考えられるが，こ

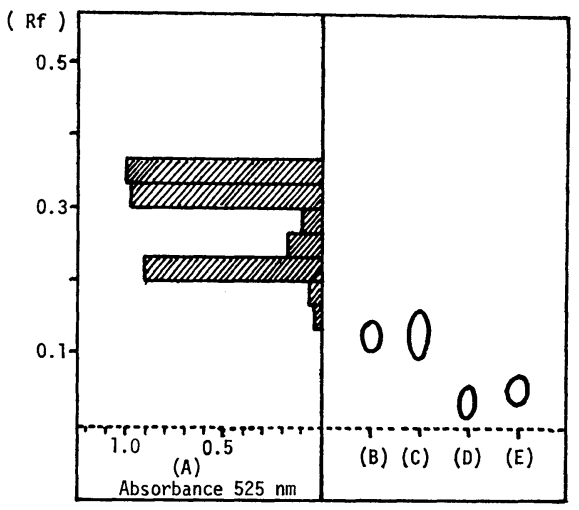

Fig. 4. Thin layer chromatogram of As-compounds

Solvent, $n$-butanol-acetone-ammoniawater (10:10:2:5); plate, PLC-cellulose (thickness; $0.5 \mathrm{~mm}$ ); spot (A) was detected with Ag-DDTC after scraped off with a spatula, spots (B-E) were detected with $5 \% \mathrm{SnCl}_{2}$ solution in $6 \mathrm{M}-\mathrm{HCl}$ and $15 \%-\mathrm{KI}$ solution.

(A), As-compound in makonbu; (B), phenyl arsonic acid (brown); (C), dimethyl arsinic acid (dark brown); (D), methane arsonic acid (dark brown); (E), potassium arsenite (yellow)

\section{こでは不明である.}

\section{7. 限外ろ過によるマコンブ中のヒ素化合物の分画}

試験溶液 II を分画分子量の異なる 3 種類のフィルタ 一でろ過したときのヒ素化合物の透過性について検討し た. 結果を Scheme 1 に示す.

分画分子量が 1,000 と 10,000 の二種類のフィルター では試料中の七素化合物の $90 \%$ 以上が外液へ溶出する が，分画分子量 500 のフィターを使用した場合では外 液へ $13 \%$ しか溶出せずヒ素化合物の $80 \%$ 以上が内液 に残留していることが判明した. このことからマコンブ 中の七素の大部分は推定分子量 500 1,000 の成分と結 合していると考えられる.

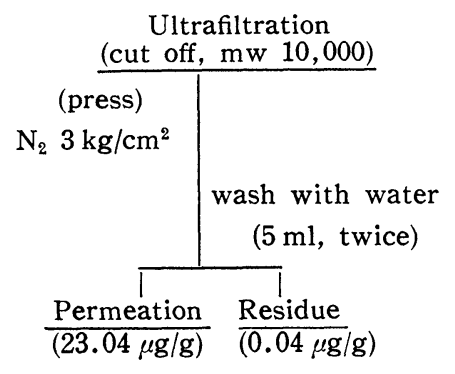

As rate in permeation $(99.8 \%)$

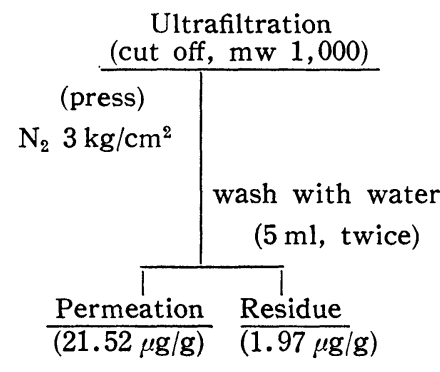

As rate in permeation $(91.6 \%)$

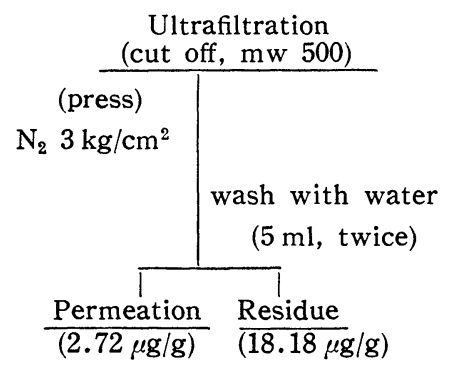

As rate in permeation

Scheme. 1. Ultrafiltration of As-compound in makonbu 
なお今後の課題としては，推定分子量 $500 〜 1,000$ の 成分と結合している大部分の水溶性七素化合物の TLC プレート上での検出試薬の検索とともに, 現在までのカ ラムクロマト等の組合せによりさらに精製率の向上に努 め, その構造解析も同時に実施する予定である.

\section{要 約}

マコンブ含有ヒ素化合物の精製を行うとともにその化 学形態について検討した.

1）マコンブ中のヒ素化合物は水ーメタノール混液 (4:1) 抽出により 9 割以上が抽出された.

2) Sephadex G-10 ゲルろ過カラムを用いて市販ヒ 素化合物（メタンアルソン酸ナトリウム, ジメチルアル シン酸ナトリウム, フェニルアルソン酸, 覀ヒ酸カリウ ム）と比較検討したところ，マコンブ中のヒ素化合物は 市販七素化合物より高分子化合物である可能性を示し た. また限外ろ過の結果から，マコンブ中のヒ素は推定 分子量 500 1,000 の化合物と結合しているものと推定 された.

3）活性炭や QAE-Sephadex A-25 によるカラムク ロマトグラフィーの検討を行ったところ, 活性炭カラム ではエタノール-水 $(1: 4)$ 混液がヒ素化合物の溶出に適 していた．カラム回収率は $99.2 \%$ でこの時の七素含有 量は $0.54 \%$ ，また強陰イオン交換体の QAE-Sephadex A-25を用いた場合も試料中の七素化合物は吸着し, 酢 酸ーメタノール（1:25）混液で溶出することが判明した。 このことはヒ素化合物が何らかのアニオン基を構成成分 に有している可能性を示している。このとき, 活性炭カ ラムで除去できなかったフェノール・硫酸陽性物質を除 くことができた. カラム回收率は $80.18 \%$, 活性炭カラ ム併用時の七素含有量は $2.78 \%$ であった.

4）セルロース TLCにおいて，マコンブ中のヒ素化 合物は，市販ヒ素化合物と異なり，ジチゾン，塩化第一
スズーヨウ化カリウムなどの発色試薬で陰性を示し, 対 照として用いた市販と素化合物とは異なった化学形態を 有していると推定された。 またこのものはニンヒドリン 反応も陰性であった。

謝辞

本研究を行うに当り多くの御助言を戴きました大阪薬 科大学小澤 貢教授, 馬場き2江講師に深謝致します。 なお本研究の一部は日本食品衛生学会第 42 回学術講演 会（昭和56年11月，大阪）で発表した。

文献

1) 山崎素直: 化学々生物 19, 148 158 (1981).

2) Lunde, G.: Environ. Health Perspect 19, 47 52 (1977).

3）田中之雄, 池辺克彦, 田中凉一, 国田信治: 食衛 誌. 18, 75 85 (1977).

4) 竹下寿雄, 前田 滋: 油化学 29, 75 81 (1980).

5) Lunde, G.: J. Sci. Fd. Agric. 24, 1021 1027 (1973).

6) Edmonds, J.S.: Tetrahedron Lett. 18, 1543 1546 (1977).

7) 安達修一, 川井英雄, 細貝祐太郎: 食衛誌. 21 , 13 18 (1980).

8）貝瀬利一，渡辺重信，池田陽男：同上 $21,58 \sim 63$ (1980).

9）福井昭三，平山晃久，野原基司，阪上嘉産：同上 22, 513 519 (1981).

10) 石崎睦雄: 分析化学 26, 667 671 (1977).

11）日本薬学会編：“衛生試験法注解” 317 330 （1973）金原出版.

12）福井作蔵: “生物化学実験法 I, 還元糖の定量法” p. 45〜47 (1979) 学会出版センター.

13）田川昭治：日水誌. 46, 1257 1259 (1980). 